\title{
Foreign News Reporting in Transition: James Perry and the French Constitution Ceremony
}

\author{
Johanne Kristiansen
}

\section{Introduction}

In the last decade of the eighteenth century, there was a shift in the practice of how British newspapers gathered news from abroad. The traditional method for acquiring such news had primarily taken the form of copying from official documents, from foreign newspapers, or from the foreign news reports printed in rival British newspapers. This copying was in some cases supplemented by short news bulletins provided by news writers based in certain European capitals, and by occasional letters from part-time correspondents stationed abroad, typically soldiers, merchants and travellers. ${ }^{1}$ However, neither the news bulletin writers nor the occasional correspondents were hired full-time, and none of them offered their services to one paper exclusively. Thus, as noted by Ivon Asquith, these practices could not be relied upon either in terms of accuracy or regularity, and they were proving inadequate when faced with the growing demand for foreign news in the period. ${ }^{2}$

The great political revolutions of the late eighteenth century had led to an increased demand for the speed and accuracy in the reporting of foreign news, especially from the various groups of people whose economic interests depended upon international affairs. Merchants, shop owners, bankers and investors all relied on newspapers for their information, and as Bob Harris notes, the newspaper was an unparalleled source of intelligence for most of its

1 For instance, the editor of 'Europe's best-informed journal', the Gazette de Leyde, paid news writers based in eight European cities to provide him with foreign news bulletins. See Jeremy D. Popkin, News and Politics in the Age of Revolution: Jean Luzac's Gazette de Leyde (Ithaca and London: Cornell University Press, 1989), pp. 71-77; Michael Harris, 'Journalism as a Profession or Trade in the Eighteenth Century', in Michael Harris and Robin Myers (eds.), $A u$ thor/Publisher Relations during the Eighteenth and Nineteenth Centuries (Oxford: Polytechnic Press, 1983), pp. 40-41. Harris does, however, point out that these casual connections could become more permanent in certain cases, so as to involve regular payment.

2 Ivon Asquith, James Perry and the Morning Chronicle 1790-1821 (Unpublished PhD diss., 1973), p. 17 .

(C) JOHANNE KRISTIANSEN, 2018 | DOI 10.1163/9789004362871_010

This is an open access chapter distributed under the terms of the prevailing CC-BY-NC-ND License, 9789004362871 
readers, and "offered far more complete coverage of politics, domestic and foreign, than most individuals' personal contacts could be expected to furnish" in the period. ${ }^{3}$ Towards the end of the century, newspaper proprietors gradually came to see the potential of this substantial demand for fresh foreign news, especially after the outbreak of the French Revolution in the summer of 1789 .

Fortunately, for the newspaper conductors, the political commotions across the channel had not only created a greater demand for news, but also a greater supply. One London newspaper - the Morning Chronicle - capitalised on this situation by sending one of its editors, James Perry, to Paris in the summer of 1791 to ensure a steady and accurate reporting of events. ${ }^{4}$ Perry's co-proprietor, James Gray, stayed behind and took sole charge of editing the newspaper in his absence. Their enterprise came at a particularly opportune moment, as several important events in France in the summer and autumn of 1791 caused an even greater demand for French news. This essay focuses on one of these events, namely the ratification of the French constitution by King Louis XVI in September 1791 .

After the outbreak of Revolution, the deputies of the newly formed 'National Assembly' had set out to reorganise French society in fundamental ways. They moved to abolish the privileges enjoyed hitherto by the nobility and the clergy, and to establish a new political system based on legal equality and popular sovereignty. The basic principles of the 'New Regime' were made explicit as early as August 1789, in the seventeen articles of the 'Declaration of the Rights of Man and Citizen', but the culmination of the National Assembly's efforts was the king's formal acceptance of a written constitution on 14 September 1791. This marked an important political shift from absolutist to constitutional monarchy, considerably limiting the king's power vis-à-vis the people.

Through the pioneering effort of James Perry, a new pattern of newsgathering emerged, with the introduction of the professional foreign reporter based at the scene of events, as opposed to the occasional contributions from parttime correspondents only loosely connected with the newspaper press. Jeremy Black argues that this earlier practice was "substantially different from a developed system of particular correspondents or agencies" that would characterise the newspaper business in the nineteenth century. ${ }^{5}$ James Perry's voyage to

3 Bob Harris, Politics and the Rise of the Press: Britain and France, 1620-180o (London: Routledge, 1996), p. 77 .

4 Jeremy Black, The English Press, 1621-1861 (Stroud: Sutton Publishing, 2001), p. 147.

5 Jeremy Black, The English Press in the Eighteenth Century (London and Sydney: Croom Helm, 1987), p. 98. By 1850 it had become customary for daily morning newspapers to have a foreign correspondent in all the major capitals in Europe. See Ivon Asquith, 'The structure, 
France marks an early attempt to create such a developed system, although it must be noted that his residence in Paris was for a limited amount of time, and that he was there not solely as a foreign correspondent, but also as a deputy of the English Revolution Society. ${ }^{6}$ Nevertheless, his connection with the Morning Chronicle was permanent and exclusive: he did not offer his reports to any competing newspapers. This early initiative thus anticipates the emergence of the full-time professional foreign reporter on British newspaper staffs.

In the years immediately following Perry's venture, other London newspapers followed his example. Both John Bell of the Oracle and D.E. Macdonnel of the Gazetteer travelled to Flanders in 1794 to report from the front. They attempted to establish a regular chain of information by hiring agents to transmit news, so that they would become less dependent on copying from other papers. ${ }^{7}$ The Morning Chronicle's leading competitor in the late eighteenthand early nineteenth centuries, the Times, also attempted to improve their foreign news service by establishing a regular chain of correspondence from Brussels and Paris, claiming that it was "through such regular channels of information only, that the public can be well and truely informed". ${ }^{\text {For some time }}$ after Perry's dispatch to Paris, however, the Morning Chronicle's competitors continued their accustomed practice of copying - this time with new source material available in the form of Perry's reports.

The objective of the following essay is to explore the political implications of this copying, and to demonstrate how challenging it could be to rely on this practice when the information provided by rival newspapers was becoming increasingly politicised. Although scholars have already noted the tendency of newspaper proprietors to send their own reporters to the scene of events in

ownership and control of the press', in George Boyce et al. (eds.), Newspaper History: From the Seventeenth Century to the Present Day (London and Beverly Hills: Constable and SAGE, 1978), pp. 98-116 (109).

6 According to the entry on James Perry in The Oxford Dictionary of National Biography, Perry stayed in Paris for almost a year, but Ivon Asquith argues convincingly that he could not have been resident there for more than eight months, and that he probably only stayed for six months, returning in time for the opening of the Parliamentary session in late January 1792. See E.A. Smith, 'Perry, James (1756-1821)', in The Oxford Dictionary of National Biography, (Oxford: Oxford University Press, 2004), online edition: http://www.oxforddnb.com/view/ article/21996, (accessed 19 May 2016), and Asquith, James Perry and the Morning Chronicle, p. 23 .

7 Asquith, James Perry and the Morning Chronicle, pp. 21-22; Robert L. Haig, The Gazetteer, 1735-1797 (Carbondale: Southern Illinois University Press, 1960), pp. 232-233; Stanley Morison, The English Newspaper (Cambridge: Cambridge University Press, 1932), pp. 32-33.

8 The Times, 25 June 1792. 
this period, the possible reasons behind this significant transition has not yet been the subject of a detailed study.

A careful analysis of the news columns of some of Perry's competitors reveals how the reporting of a politically fraught event, such as the royal ratification of the new constitution, challenged the existing methods for newsgathering in a time of exceptional political strife and vicissitudes. ${ }^{9}$ The Morning Chronicle was a self-confessed opposition paper in support of the Revolution, and this article will demonstrate how the political tenor of Perry's reports changed when they were incorporated into the columns of newspapers with conflicting political leanings. As other newspapers copied the comprehensive accounts of this reporter at the scene of events, they sought to avoid his most politically charged observations by selecting only certain paragraphs, and paraphrasing others based on alternative sources, in order to accommodate the information to their own political stances. This would at length prove to be a difficult task. The intensely polarising issue of the French Revolution - and the political journalism inspired by it - not only complicated the process of copying foreign news reports from papers with a conflicting political orientation, but it also challenged contemporary conceptions of the validity of existing sources of foreign news altogether. In order to secure what was believed to be a trusthworthy and unbiased report of events, newspaper proprietors would in the century to come rely less on copying from other newspapers and more on the reports provided by their own foreign reporters.

\section{Reporting the Revolution: The London Morning Dailies}

With no regular foreign correspondents of their own, London newspapers other than the Morning Chronicle relied on traditional sources and newsgathering methods in order to cover the important events unfolding in France. One source commonly resorted to was the aforementioned letter correspondence from individuals abroad, but these were casual arrangements that proved too irregular to be relied upon as steady and accurate sources of foreign news. A more stable, and much more authoritative, supplier of information about foreign affairs was the London Gazette, the official government paper. As stated in a large blackletter font on the paper's title page, the Gazette was "published by authority", and through this state sponsorship its editors had access

9 This paper focuses on the Times, the World, the Public Advertiser, the London Chronicle, the St. James's Chronicle and Lloyd's Evening Post. This selection is based on the newspapers available for this period in the Burney Collection and the Times Digital Archive. 
to important state documents from British Ambassadors and military officers stationed abroad. Because of these usually reliable sources, the contents of the Gazette were often copied into the commercial newspapers, especially in times of international crisis. ${ }^{10}$ In the case of the signing of the constitution, however, the London press could not rely on the Gazette, because its columns contained no mention of the ceremony whatsoever. This was a conspicuous omission that did not go unnoticed. The St. James's Chronicle commented that it was "remarkable that the London Gazette has taken no sort of notice of the King of France's acceptance of the New Constitution", and speculated whether the recent death of the Ambassador might be the reason for the delay in the official communications. ${ }^{11}$

In this situation, another frequently utilised source proved especially valuable, namely the foreign newspaper press. Prior to the Revolution, the London press had depended largely on newspapers published outside of France for their French news, such as the French-language Gazette de Leyde from Holland. The newspapers published in France itself were so tightly controlled by the authoritarian government that they would give no true account of political affairs. After the Revolution, however, a "virtually unregulated" albeit short-lived French domestic press was allowed to prosper, providing the London press with a valuable new source of information. ${ }^{12}$ London newspaper conductors subscribed to these papers, and spent much time and money on translating them in order to insert their contents into their own columns..$^{13}$ According to Jeremy Black, the dependence on foreign newspapers reached its climax during the French Revolution and the subsequent wars between Britain and France. ${ }^{14}$ Indeed, a mistake in the delivery of the French newspapers to the office of the Times in October 1791 shows how dependent the London press was

10 Michael Harris, 'London newspapers 1695-1830', in Michael F. Suarez and Michael L. Turner (eds.), The Cambridge History of the Book in Britain, vol. 5 (Cambridge: Cambridge University Press, 2009), pp. 413-433 (420).

11 The St.James's Chronicle, 22-24 September 1791.

12 Jeremy D. Popkin, Revolutionary News: The Press in France, 1789-1799 (Durham, NC: Duke University Press, 1990), p. 32.

13 The following advertisement appeared in the Times on 27 August 1792: "Wanted immediately, A Gentleman who is capable of translating the French language. In order to prevent trouble, he must be a perfect Master of the English Language, have some knowledge of the Political State of Europe and be thoroughly capable of the situation he undertakes. His employment will be permanent and take up a considerable share of his attention; for which a handsome salary will be allowed". The History of The Times, vol. 1: 'The Thunderer' in the Making, 1785-1841 (London: The Times Publishing Company, 1935), pp. 41-42.

Black, The English Press in the Eighteenth Century, p. 89. 
on the foreign gazettes in this period: having not received the French papers, the Times was apparently unable to report any news from France that day. As French news by this time had become the unrivalled topic of public interest, this was an omission for which the conductors were "extremely sorry". 15

In the autumn of 1791, a new source of Parisian intelligence emerged with the publication in the Morning Chronicle of James Perry's authentic first-hand reports. The dispatch of Perry to the French capital enabled the editors, in their own words, to "give an earlier account of what is passing there than any of our competitors". ${ }^{16}$ Ivon Asquith notes that Perry's summary of events in Paris had one day's priority, and that his reports of the proceedings in the National Assembly had two day's priority, but he does not explain the logistics of this operation: how was Perry able to dispatch his reports sooner than others? ${ }^{17}$ The details of how Perry's accounts travelled from Paris to London are not completely clear, but it is possible to make certain conjectures. Based on the often abrupt endings of Perry's accounts, he seems to have been in a hurry to reach the deadline for outgoing mails. Perry could dispatch his hand-written notes as soon as he had finished writing them, whereas the conductors of other London newspapers - who relied on the French gazettes for their news from France - would have to wait for the French reporters to deliver their notes to the printer; for the composers to set type; and for the printer to print the final product, before the newspapers could be shipped to London. They would also have to spend extra time and resources on translating the reports from French to English once the newspapers arrived.

The Morning Chronicle's ability to provide an early account of events was an advantage that boosted its sales, and while Perry was residing in Paris as a foreign correspondent, his early reporting of French affairs often resulted in verbatim reproductions in the other London newspapers. ${ }^{18}$ Not only is this clear from a comparison of the newspapers themselves, it was also frequently pointed out by the Morning Chronicle's editors, who complacently mocked the other newspapers for "filling half their columns" with "[e]xtracts from the MORNING CHRONICLE". 19 There was nothing new in newspapers copying each other's reports, or in newspaper conductors pointing this out to readers. However, in the period of James Perry's residence in Paris his reports in particular were frequently copied, presumably because he was considered to provide

\footnotetext{
15 The Times, 25 October 1791.

16 Black, The English Press, 1621-1861, p. 147.

17 Asquith, James Perry and the Morning Chronicle, p. 18.

18 Black, The English Press, 1621-1861, p. 147.

19 The Morning Chronicle, 11 January 1792.
} 
the most accurate and up-to-date news from France. This is supported by a letter published in the popular and much circulated Gentleman's Magazine, where the correspondent notes:

Though I was in Paris when the King accepted the new Constitution, I was not present at that ceremony; but I know that what passed on that memorable day has been faithfully related by (I believe) Mr. Perry, in the "Morning Chronicle" of the 23 rd of September. ${ }^{20}$

A main goal of establishing Perry as a foreign correspondent had been to secure an accurate, punctual and trustworthy delivery of news. Unfortunately, this did not always go according to plan. In the days following the signing of the constitution, there had been a delay in the shipment of mail from France to England. On 20 September, six days after the constitution ceremony, the Morning Chronicle apologised for not giving an account of this important event, explaining that they had not received their expected accounts from France the preceding day. ${ }^{21}$ The post having not yet arrived the following day, a general apprehension had broken out in London, as described in a paragraph from the St.James's Chronicle:

The commercial part of the town has been in somewhat of a ferment for these two days past. Ever since the 14th no letters have been received from France, yet the wind has been during a considerable part of that time not unfavourable, and for a short space even favourable. What can have occasioned this delay, in the correspondence with that kingdom does not appear, but no mails, no letters of any sort having arrived, it looks as if the post was entirely stopped, though to what to attribute this is beyond the power of conjecture. ${ }^{22}$

Apparently, it was not so far beyond the power of conjecture as to deter the writer from speculating on possible causes, and he points to popular unrest

The Gentleman's Magazine, October 1791, 61 (4). That Perry's reports were perceived to be the best sources of French news is further evidenced by a correspondence between the two opposition MPs George Tierney and Charles Grey. Tierney noted to Grey that "of French news, I can give you no better than what the Morning Chronicle affords", demonstrating that even well-connected people who moved in high social circles looked to the Morning Chronicle for updates on the situation in Paris. See Asquith, James Perry and the Morning Chronicle, p. 23.

21 The Morning Chronicle, 20 September 1791.

22 The St.James's Chronicle, 20-22 September 1791. 
due to the shortage of bread, and a possible insurrection resulting from this, as the most probable cause. In other words, political crises and weaknesses in existing distribution systems could interrupt the flow of news, despite the innovations made by individual newspaper entrepreneurs. Thus, the Morning Chronicle could not always secure priority of intelligence.

Finally, on 23 September, the Morning Chronicle had received "no less than four packets from Paris", and, despite the delay, they nevertheless contended that they would "certainly anticipate most of [their] contemporaries" when laying this news before the public. ${ }^{23} \mathrm{~A}$ survey of the other London dailies on the same day shows that, in fact, they had not been able to anticipate their competitors in terms of speed. What is clear, however, is that they certainly outstripped them in terms of detail and volume. James Gray noted how the sheer amount of information contained in the four received packets made it "impossible ... to lay a particular detail of each before [their] readers in one day" and he had consequently "been at pains to select the most important and interesting". ${ }^{24}$ This wide selection, combined with Perry's frequent use of the first person singular, gave the Morning Chronicle an edge that the other London dailies simply could not match. As Ivon Asquith points out, the first person singular draws attention to the fact that Perry's reports are "authentic and first hand". ${ }^{25}$ For instance, he opens his description of the constitution ceremony by pointing out how he had been "fortunate enough to get a place in the Tribune of Suppliants, exactly opposite to the President, and not more than ten or twelve yards distant - so that I commanded a full view of the scene. I mention this fact, only to prove that my relation is likely to be correct". ${ }^{26}$ The superiority of Perry's report in terms of detail and scope is evident when we compare it with the reports of the other London dailies. When describing the ceremony, the World and the Public Advertiser only provide the reader with brief, factual information:

A few minutes past twelve o'clock, the KING entered by the left side of the Hall, escorted by his Ministers, and preceded by a Deputation of twelve Members of the National Assembly, sent to meet him. The KING was not distinguished by any of the ornaments which have been reserved to him. ${ }^{27}$

23 The Morning Chronicle, 23 September 1791.

24 The Morning Chronicle, 23 September 1791.

25 Asquith, James Perry and the Morning Chronicle, p. 19.

26 The Morning Chronicle, 23 September 1791.

27 The World, 23 September 1791. 
After this sparse explanation, the World immediately moves on to a circumscribed account of the king's speech in acceptance of the new constitution. In contrast, Perry's report abounds with detailed descriptions of how the Hall of the Assembly was decorated on this grand occasion:

At twelve o'clock precisely they prepared the Assembly for the Royal Sessions. The table of the Secretaries had been removed from the platform, and was placed on the ground, just before the Bar. The President's table, and ordinary chair, were now removed, and a carpet, of a purple ground, embroidered with fleurs-de-lis in gold, was spread over part of the elevated platform to the left. A chair of the same colours was placed on this carpet. A chair of the same workmanship, but the ground blue, and the fleurs-de-lis not so numerously embroidered, was placed to the right of the carpet for the President. ${ }^{28}$

The attention to detail in Perry's report clearly shows the advantages of his physical proximity to the event, and must have been far more gratifying to avid readers who hungered for news from the French capital than the short remarks offered by the World and Public Advertiser. Importantly, however, Perry's firstperson narrative not only lends credibility and richness of detail to his reports, but also blends the reporting of events with his political beliefs.

\section{The Politics of News}

Although Perry's proprietorship of the Morning Chronicle had made him a wealthy man by the time of his death in 1821 , he came from humble origins. He was the son of an Aberdeen carpenter, and had been so fortunate as to matriculate at Marischal College in 1771, although he was forced to leave without completing his degree three years later when his father's business failed. ${ }^{29}$ He then had to earn his own living, and worked as an attorney's clerk and as an assistant in a draper's shop, before entering a theatrical troupe only to be told that he would never make it as an actor south of the border because of his thick Scottish accent. He nevertheless had a great talent for oratory, and attended public debating societies after moving to Manchester, and then in

\footnotetext{
28 The Morning Chronicle, 23 September 1791.

29 He had purchased the paper jointly with Gray in 1790 for a mere $£ 210$, but around the time of his death the newspaper secured him an annual profit of $£ 12,000$, and when he died the paper was sold for $£ 42,000$. See E.A. Smith, 'Perry, James (1756-1821)'.
} 
London, where he settled down at the age of twenty-two. Indeed, his talent was so great that William Pitt himself had suggested he go into Parliament. ${ }^{30}$ Perry never embarked on a Parliamentary career, but his political convictions were so strong that they became a deciding factor in his career as a newspaper editor and proprietor. Before buying the Morning Chronicle, Perry was asked to be editor of the Gazetteer and New Daily Advertiser in 1783, a position he accepted only "on the express condition that he was left to the free exercise of his political opinions, which were those asserted by Mr. [Charles James] Fox". ${ }^{31}$ In particular, it was Fox's reputation as the 'Man of the People' and champion of their liberties - especially the liberty of the press to report and comment freely on the transgressions of government - that attracted Perry. Like most other newspaper proprietors in the period, Perry was not above accepting subsidies from politicians, and his links with the Foxites are obvious from a perusal of the pages of the Morning Chronicle, and are even made explicit in the opening address to readers in December 1790, when Perry and Gray had bought the ailing Morning Chronicle from the exhausted printer-proprietor William Woodfall. ${ }^{32}$

Nevertheless, Perry's political support of Fox was genuine and unconditional throughout the 179os, despite having to swim against the tide of public opinion for most of the decade. This genuine support is demonstrated in part by the fact that there were clearly fewer advantages in supporting the opposition than the ministry, because the government had far more resources available in order to control the press. For one thing, the ministry had Secret Service funds at their disposal, whereas the members of the opposition had to pay for press subsidies from their own pockets. Furthermore, the ministry could intimidate the press into submission in ways that were not available to the opposition, for instance by raising taxes, by prosecuting ex-officio for seditious libel, or by blocking their access to information. ${ }^{33}$ Indeed, it was hardly a coincidence that the enterprise shown by Perry and Gray in the summer of 1791 came from newspaper proprietors with political ties to the opposition, rather than the government. As argued by Ivon Asquith, their investment in the foreign news service was perhaps an attempt to counter the advantages enjoyed by the ministerial press, whose political connections provided far greater access to domestic news. ${ }^{34}$ In other words, Perry's unwavering support of Fox probably

\footnotetext{
3o Haig, The Gazetteer, 1735-1797, p. 189 .

$31 \quad$ Ibid

32 The Morning Chronicle, 13 December 1790.

33 Lucyle Werkmeister, The London Daily Press, 1772-1792 (Lincoln: University of Nebraska Press, 1963), p. 318.

34 Asquith, James Perry and the Morning Chronicle, pp. 16-17.
} 
afforded him more inconvenience than advantage, but his political principles were so strong that he was willing to countenance these drawbacks in order to pursue what he deemed to be the greater good.

Perry's political convictions shape his lengthy account of the ceremony and of the public celebrations following this event, which "to the eye of reason, and philosophy, ... was, and must be considered by enlightened posterity, as the grandest event of the antient or the modern world". ${ }^{35} \mathrm{He}$ describes the enthusiastic, but peaceful, celebration that followed the signing of the constitution, and he takes great pains to stress the moderation of the Revolution in order to downplay its violent reputation:

Through the whole of the rejoicing on this event, the people have manifested a tranquil and peaceable spirit ... There was no tumult, no drunkenness, no disorder; and that ferocious democracy, which has been so trumpeted and abused, was no where visible. ${ }^{36}$

It was important for Perry to stress the peaceful nature of the public celebrations, especially because Edmund Burke's famous conservative pamphlet Reflections on the Revolution in France had produced a powerful hold on the public imagination. By drawing on violent episodes from the Revolution, Burke had managed to create a lasting impression of the vices and transgressions of the revolutionaries, and he succeeded in conjuring up ideas and tropes that would act as a warning to all reformers in Britain, lest they should attempt to change in any way the balance of the British constitution. ${ }^{37}$ Thus, when Perry takes such great pains to stress the moderation of the public festivities, he enters into an explicitly politicised debate about the prospects of effecting political and societal change without violence and chaos.

Another example of how Perry's political opinions influence his news reporting, is his comparison between French and British institutions and practices that put the latter in an unfavourable light. This is especially apparent in his discussion of an issue that affected his own business directly, namely the

35 The Morning Chronicle, 23 September 1791.

36 Ibid.

37 For a more detailed account of Burke's impact, see the chapter 'Edmund Burke: Reflections on the Revolution in France (1790) and the Origins of Conservatism' in Gregory Claeys, The French Revolution Debate in Britain: the Origins of Modern Politics (Basingstoke: Palgrave Macmillan, 2007), pp. 11-48 and David Bromwich, 'Burke, Reflections on the Revolution in France', in Pamela Clemit (ed.), The Cambridge Companion to British Literature of the French Revolution in the 179os (Cambridge: Cambridge University Press, 2011), pp. 16-31. 
fraught question of press freedom. By describing how the French newspaper reporters were given excellent seats in the Assembly in order to produce the best possible account of events, Perry explicitly points to the shortcomings of existing British regulations:

The writers ... were accommodated with places for the day in the body of the Hall; for so properly attentive is the Assembly to the true interests of the people, that, for the sake of publishing correct accounts of the proceedings, the respectable Papers have bureaus and places allotted to them, that they may write the accounts on the spot. There is none of the affected prudery on this subject, by which knowledge is sacrificed to the unbecoming pride of the English Parliament. ${ }^{38}$

In the 1760 s, the British press had fought for the right to report the activities of Parliament, and had won the right to do so in $1771 .{ }^{39}$ However, this did not necessarily mean that journalists were free to report debates as they saw fit, and there were important restrictions to their newly won freedom. For one thing, reporters were not allowed to take any notes, and had to report the proceedings of Parliament from memory. ${ }^{40}$ In addition to this, journalists could be forced to leave the gallery of the House, if the MPs suspected that any 'strangers' were there to spy on them..$^{41}$ In contrast, Perry notes how "the politeness of the Assembly yielded to the eager curiosity of the people, by admitting numbers of foreigners, and others, to seats in the body of the Assembly" and that "in all there could not be fewer than 3000 strangers present". 42 Not only were these 'strangers' allowed to witness the ceremony, they were moreover afforded a place in the body of the Assembly, as opposed to the galleries.

It is significant that Perry criticises the administration in such a direct and forceful manner. No newspaper that was subsidised by the Pitt ministry would dare incorporate these sentiments into their own news reports for fear of possible repercussions, despite Perry's objective being in line with their own interests. England was renowned in the period for its free and uncensored press, but the governing authorities could in fact depend on several mechanisms

38 The Morning Chronicle, 23 September 1791.

39 For an overview of this important development, see P.D.G. Thomas, 'The Beginning of Parliamentary Reporting in the Newspapers, 1768-1774', English Historical Review, 74 (1959), pp. 623-636.

$40 \quad$ E.A. Smith, 'Perry, James (1756-1821)'.

41 Harris, Politics and the Rise of the Press, pp. 40-41.

42 The Morning Chronicle, 23 September 1791. 
designed to keep the press in check. Most importantly, printers and newspaper proprietors were under constant risk of being prosecuted for publishing libellous material, and this functioned as a serious impediment to the alleged press freedom. One of Perry's leading competitors in the period, John Walter of the Times, had personally felt the consequences of this restricted freedom, when he was prosecuted for publishing a libel on the Prince of Wales and his brothers in 1789, and was sentenced to two years in prison. The paragraph had not been written by Walter himself, but in return for political subsidies from the Treasury, he had agreed to insert political paragraphs written by government hirelings. Instead of revealing the true identity of the writer, Walter kept his mouth shut, for fear of losing his political subsidy. ${ }^{43}$ In other words, Perry's comparison between French and English conditions is clearly involved in an ongoing and extremely contentious debate surrounding press freedom in Britain.

\section{Copying Political News: The London Triweeklies}

The evident political tendencies of Perry's reports would prove challenging for some of his competitors, especially the conservative evening papers published three times a week. These publications had dominated the London market in the first half of the century, but by 1775 the morning dailies had come to surpass them in terms of sales and significance. ${ }^{44}$ This is an indication of the rising appetite of readers in the period: by the late eighteenth century, the demand for updated news had become so great in London that there was now a larger market for daily than triweekly publications.

As discussed above, there had been a delay in the mail delivery from France, which meant that Perry's lengthy account of the constitution ceremony was not published in advance of the reports of other daily newspapers. Thus, the London daily press could not copy from Perry's report, and had to resort to other sources when covering the ceremony. The same problem did not present itself to the triweekly papers. They were published in the evening and only three times a week, which made them especially able and likely to copy from the London morning papers. Jeremy Black suggests that it was not necessary for provincial newspaper proprietors to subscribe to foreign newspapers and

\footnotetext{
43 Hannah Barker, 'Walter, John (1739?-1812)', in The Oxford Dictionary of National Biography (Oxford: Oxford University Press, 2004), online edition: http://www.oxforddnb.com/ view/article/28636 (accessed 19 May 2016).

Harris, 'London Newspapers', p. 424.
} 
spend large amounts of money on translating their contents, when they could rely on the London press. ${ }^{45}$ Black is referring to the provincial press, but the same logic can be extended to the London triweeklies which, because they were published only three times a week and late in the evening, had plenty of English sources to rely on, without having to pay large sums on subscriptions to foreign papers and on hiring translators.

It is particularly interesting to explore how these triweeklies copied from the news columns of the Morning Chronicle, because they mainly catered to a conservative audience based in the English countryside. Scholars have pointed out that the London triweeklies were "specifically designed for a provincial readership", or "aimed primarily at the country reader". 46 This is clear from the fact that the publication of these newspapers was timed to correspond with the outgoing mails from London to the provinces, in other words on Tuesdays, Thursdays and Saturdays. According to Michael Harris, 4,650,000 copies of London newspapers were distributed to the provinces through the Post Office in $1790 .{ }^{47}$ This distribution was very expensive, unless the recipient was able to acquire his copy through the franking system.

In the eighteenth century, MPs and the Clerks of the Roads had the privilege of sending newspapers free of charge through the post in franked envelopes, and, in fact, the charges of sending them unfranked were so high that "no one even considered paying them". ${ }^{48}$ The fact that it was so expensive to acquire a London triweekly meant that country subscriptions were restricted to the powerful and well-connected. Admittedly, one could turn to the Clerks of the Roads, who through their franking privilege could earn good money on distributing newspapers to country subscribers, but while their franking charges were lower than the postal charges, they were still high enough to place the London triweeklies out of reach for the lower orders. The high cost of the London triweeklies points to an audience firmly rooted in the social and political elite, constituted by "the local gentry, the clergymen and the town magnates". ${ }^{49}$ For this reason, it is particularly interesting to explore how the conductors of these

Black, The English Press in the Eighteenth Century, p. 89.

46 Michael Harris, 'The Structure, Ownership and Control of the Press, 1620-1780', in George Boyce et al. (eds.), Newspaper History: From the Seventeenth Century to the Present Day (London and Beverly Hills: Constable and SAGE, 1978), pp. 82-97 (87), and G.A. Cranfield, The Development of the Provincial Newspaper, 1700-176o (Oxford: Clarendon Press, 1962), p. 180. 
newspapers dealt with news reports from a newspaper directed at a much less conservative audience than their own.

Taking their political inclinations into account, one may ask why the London triweeklies would copy from the Morning Chronicle at all. As discussed above, Perry's report had the clear advantage of being a first-hand account, both authoritative and meticulous in its attention to detail. It seems as though the triweeklies could not resist this advantage, because several newspapers copied paragraphs verbatim from Perry's report. In the pages of both the London Chronicle and Lloyd's Evening Post, we find Perry's exact formulations, without his words being attributed to either him or the Morning Chronicle. As opposed to the London Chronicle, which has at least left out or paraphrased the sentences containing the personal pronoun, Lloyd's Evening Post has conspicuously chosen to retain them:

THE grand event is past, and the Constitution of France has received the signature of the King. I will give you a circumstantial detail of the proceedings of yesterday: The anxiety of the public to be present at the ceremony was so great, that hundreds remained all night in the Hall of the Assembly. When I went at seven o'clock in the morning, I found all the galleries full to overflowing. ${ }^{50}$

The conductors may have chosen to keep the personal pronoun to extend the authenticity of Perry's report to their own newspaper. The paragraph above, and others similar to it, would be safe to reproduce, because it contains no controversial political hints. It is crucial to note, however, that Lloyd's ends its verbatim copying at the exact place where Perry began his contentious critique of British press freedom. Similarly, the London Chronicle silently skips Perry's political expostulations, before returning to their word-for-word reproduction of his report. ${ }^{51}$

Other newspapers were more selective in their approach. The St. James's Chronicle was a decidedly conservative newspaper. It accompanied its reporting of the constitution ceremony with the publication of a letter signed "Many of the People", defending the integrity of the king from attacks by a "French Revolutionist, very zealous in making new proselytes".52 In light of their own political stance, the incorporation of Perry's report into the columns of the St. James's Chronicle could not have been an easy task. In fact, it seems as

50 Lloyd's Evening Post, 21-23 September 1791.

51 The London Chronicle, 22-24 September 1791.

52 The St.James's Chronicle, 22-24 September 1791. 
though the greater part of Perry's report was deemed unfit for reproduction, because - although what they actually did include was reproduced wordfor-word - it can hardly be said to draw heavily on Perry's account. The only paragraph taken from the Morning Chronicle is this:

Yesterday, for the first time since the journey to Varennes, the King took an airing on horseback. Upon His Majesty's arrival at the drawbridge, a vast concourse of people, who had been drawn together by the report of his design to take an airing, and a desire to see him, hailed him with repeated and sincere shouts of Vive le Roi - An affecting joy was visible in his countenance at these marks of love and attachment. ${ }^{53}$

This tiny paragraph, undoubtedly the least controversial and most royalist to be found in Perry's account, is the only one from the entire report to be included, despite the report spanning seven columns and almost two whole pages. When compared with the rest of Perry's report, it is quite striking how little the St.James's Chronicle actually decided to include. The editors seem to have avoided the political implications of the original source simply by selecting its copied materials very discriminately.

Another interesting detail in the same issue is their account of the public celebrations following the ceremony. As previously mentioned, it was important for Perry to highlight the tranquillity and nonviolence of the revolutionists when describing the public celebrations. These comments were highly politicised and, as with several other politically controversial paragraphs, both the London Chronicle and Lloyd's Evening Post refrained from copying these remarks. The St. James's Chronicle took another approach. Instead of simply skipping Perry's descriptions of the peaceful celebrations, they published their own version, in stark contrast to the one offered by Perry. Under the headline "SUNDAY'S FETE", we find the following:

All Paris was up before the sun, though not all for the same reason - the favourers of the new theory rose to celebrate the festival of the Constitution, and pay their early homage to a code of laws that put the servant on a footing with his master; but they were so vociferously patriotick, and so petulantly merry, that they roused the friends of tranquility from their soft slumbers and forced them into a chaos of noisy mirth (my emphasis). ${ }^{54}$

53 Ibid.

54 The St.James's Chronicle, 22-24 September 1791. 
This paragraph is teeming with significant rhetorical devices, building on the aforementioned impression made on the British public by Burke's famous pamphlet. Describing the revolutionists as vociferous and petulant, and their celebrations as a "chaos of noisy mirth", the writer draws the reader's attention to one of the main themes of Burke's pamphlet, namely the transgressions of the revolutionists, who were deemed to be self-seeking and greedy amateurs whose knowledge and experience were insufficient for the governing of a country. ${ }^{55}$ Burke's strongest attack on the revolution, however, was based on his dismissal of the abstract principles of the 'natural rights of man', which the writer in the St.James's Chronicle is alluding to in his comment about the 'new theory'. Burke had established a conservative precedent for derisive comments about this new theory, by pointing out the absurdity of establishing a political framework upon abstract theories rather than actual knowledge of political institutions and their proven success - in other words upon knowledge that could only come with experience and tradition. Naturally, this would exclude a large majority from exercising political power, for who other than the ruling elite would have the experience Burke is calling for? Indeed, Burke is known for his notoriously condescending remark about mob rule by the "swinish multitude", and for his idea that the tyranny of the few would be replaced by the tyranny of the many, which was much worse. ${ }^{56}$ The writer in the St. James's Chronicle is alluding to this when he describes the French constitution as a "code of laws that put the servant on a footing with his master", a remark that also echoes long-standing and unpleasant associations with the Leveller movement of the Civil War period. This version of the public festivities provided by the St.James's Chronicle is exclusive to their paper. Fortunately, the conductors have provided a clue under the headline "Authentick advices", by explaining that this piece has been provided by "the Correspondent of the St. J. Chronicle resident at Paris", and this is a good example of how these sporadic communications could supplement the information gained from other sources (or, as in this case, replace it). ${ }^{57}$ By exploring the news columns of the St. James's Chronicle, it seems that this particular paper has solved its dilemma by opting for an extremely careful selection combined with the construction of alternative narratives based on other sources that were available to them at the time.

A greater and more complex engagement with Perry's report can be found in Lloyd's Evening Post when their substantial verbatim copying gives way to a

\footnotetext{
55 Claeys, The French Revolution Debate in Britain, p. 16.

56 Ibid., p. 13; David Duff, 'Burke and Paine: contrasts', in Clemit (ed.), The Cambridge Companion to British Literature of the French Revolution in the 179os, pp. 47-71. 
construction of an alternative narrative in their description of the ceremony itself, and of the dynamics between the king and the National Assembly in particular. Perry and several of the London daily newspapers devoted much space to a debate that took place in the Assembly prior to the king's arrival, namely whether the Assembly, as representatives of the nation, should stand or remain seated while the king took the oath of fidelity, and whether or not they should remove their hats as a tribute to him. Some representatives suggested that they should stand and take their hats off, because the king, as the supreme chief of the whole nation, should be received with all possible respect. The majority, however, wished to remain seated, to express the sovereignty of the people vis-à-vis the king. They decided to receive him standing, but to be seated while he spoke.

Despite large chunks of Perry's report having hitherto been copied verbatim by Lloyd's, many sentences and paragraphs had admittedly been paraphrased, even before arriving at the description of the king and the National Assembly. However, apart from the places where certain controversial paragraphs have been skipped, this paraphrasing seems to have been an attempt to save space rather than an effort to avoid political controversy, because - although many of Perry's original sentences have been changed - the content of his report is still very much the same.

This is not the case in Lloyd's depiction of the dynamics between the king and the National Assembly. When arriving at this important part of Perry's report, the verbatim copying stops completely, and continues by paraphrasing alone. Furthermore, at this point, the nature of the paraphrasing itself changes: the information presented to the reader is no longer similar in content to the information we gain from Perry's report. In fact, Lloyd's provides a completely contrasting narrative of the conduct of the National Assembly towards the king, and also of the latter's reaction to this notable decline of respect, power and prestige. According to Perry, the king, upon ascending the platform where his chair was placed, "began instantly to read, without sitting down, and without any previous ceremony". 58 When recounting his speech, Perry interrupts several times with explanatory remarks that paint a rather awkward picture of the king:

I swear (here the President sat down, and his example was followed by the Assembly) to be faithful to the Nation and the Law; and to employ all the power that is delegated to me, to maintain the Constitution decreed by 
the Constituting National Assembly. (At this moment, the King turning his head to the right, observed [the President] seated - He looked round, and saw all the Members to the left seated, and one or two with their hats on - He instantly sat down - He did it in a manner which testified an embarrassed emotion - but recovering himself - he proceeded, sitting, with the only remaining sentence of his paper). ${ }^{59}$

In other words, Perry describes an uncomfortable and perplexed king, and draws the reader's attention to his distress and humiliation. ${ }^{60}$ The report in Lloyd's describes a very different king, one who entered the Assembly with confidence, and "looking around with a cheerful air" - gave his speech in the following manner:

"I swear - (on this the Deputies sat down) to be faithful to the Nation and to the Law, to employ all the power delegated to me, to maintain the Constitution decreed by the National Constituent Assembly, and to cause the Laws to be executed. [Loud plaudits; in the midst of which the King sat down] The King, having again risen, continued as follows: May this great and memorable epoch be that of the re-establishment of peace and union, and may it become the pledge of the happiness of the People, and the prosperity of the Empire!" [The Hall resounded for several minutes with gratulations of joy; after which the patriotic side of the House began new acclamations, by repeated cries of "Vive le Roi!"]. ${ }^{61}$

If we compare the two, we clearly see how Lloyd's has removed all the humiliating details concerning the king's perplexed state of mind on this formal occasion. Moreover, they add their own comments that we cannot find in Perry's report at all, comments that place the king in a very positive light. According to Lloyd's Evening Post, the king sat down due to loud applause, rather than humiliation, and there is in general a great emphasis on the respectful attitude of the Assembly towards the king. It is important to point out that this

59 Ibid.

6o It is important to note that the word 'embarrassed' did not carry the same meaning in the eighteenth century as today. According to the 6th edition (vol. 1) of Johnson's Dictionary, published six years prior to the constitution ceremony, 'embarrassed' signifies the feeling of being perplexed or distressed. In any case, Perry is describing a king who is clearly uncomfortable and not in control of the situation. Lloyd's Evening Post, 21-23 September 1791. 
information is not fabricated. It is most probably drawn from one or more of the London dailies, several of which report on the excessive plaudits and " $\mathrm{r}]$ epeated shouts of long live the King?!.62

Indeed, we may draw Perry's own trustworthiness into question, because despite being an eyewitness to the event - he has refrained from commenting on the loud plaudits from the more conservative members of the National Assembly, which seems to be quite essential information. His depiction of the king, it must be noted, seems to be a sound interpretation, corroborated by a statement in the Times that "it was evident that his voice faultered, that his countenance was pale, and, that he was exceedingly embarrassed".63 It is nevertheless interesting that Lloyd's Evening Post has decided to place such emphasis on the loud plaudits, and that they suddenly depart so conspicuously from Perry's report, after having hitherto depended so heavily upon it. It is clear that they are no longer paraphrasing simply to save space, but also to avoid the political implications of Perry's report.

\section{Conclusion}

The heightened demand for the prompt and accurate reporting of foreign news in the aftermath of the French Revolution inspired newspapermen to provide accurate and timely information, leading to Perry's pioneering effort in the summer of 1791. His enterprise changed the framework for foreign news reporting in England, and inspired later efforts by other newspaper proprietors to improve their own foreign news coverage. The Oracle and the Gazetteer sent reporters to the front at Flanders in 1794, in an effort to establish a regular chain of information. The leading competitor of the Morning Chronicle in the period, the Times, also made an effort to improve its foreign news coverage by establishing a regular chain of correspondence from Brussels and Paris in May 1792. The news articles provided through this new channel were singled out as especially important through the use of the headline "Original Correspondence", and in an editorial note on 22 May 1792 the editor stressed the expediency of this arrangement:

The good arrangement and expedition of our new Foreign Correspondence we trust, will be sufficiently evinced by our News from Paris in this day's Paper, which though not extremely important in itself, proves the

62 The World, 23 September 1791.

63 The Times, 23 September 1791. 
means we have taken to obtain it. We yesterday received letters from Paris of TWO days later date than those brought by the ordinary Mail. ${ }^{64}$

A month later, they appealed to the discernment of the public, and trusted that they would be able to "distinguish in this Paper between the vague reports caught at by other Morning Prints, and the authentic Communications which come to us by every Mail from Brussels, Paris, Vienna, \&c", and they end their address to readers by claiming that it is "through such regular channels of information only, that the public can be well and truely informed". ${ }^{65}$

Stanley Morison suggests that it was the initiative of Bell that had provoked the Times to improve their own foreign news coverage. ${ }^{66}$ However, since Bell travelled to Flanders as late as 1794, it is clear that the initiative of the Times was due rather to Perry's efforts the preceding year. Prior to this initiative, the London press had relied primarily on copying from the government sponsored London Gazette and foreign newspapers, as well as irregular contributions from correspondents abroad. These newsgathering methods continued to dominate both during and after Perry's venture and, as Jeremy Black points out, "the practice at the end of the century was still essentially the same as that at the beginning". ${ }^{67}$ James Perry's enterprise had nevertheless clearly pointed out the benefits of having a steady and permanent flow of intelligence from Paris to London. This inspired similar initiatives by competitors, and there is no doubt that the entrepreneurial efforts of the Morning Chronicle form part of an emerging systemic shift in the practice of foreign news gathering towards the end of the eighteenth century.

This development was driven in large part by the pursuit of economic gain, but it is nevertheless clear that there were also political motivations at play. After having described the constitution ceremony, Perry claimed to have "forborne all observations of [his] own on this unexampled scene". 68 His competitors, with differing political sympathies, would hardly agree with his assertion. The political tenor of his news reports posed significant challenges for them, and they were forced to select carefully or paraphrase the material in order to accommodate it to their own newspaper columns. As the Revolution became radicalised from 1792 onwards, newspaper editors were finding it increasingly difficult to evaluate the reliability of their sources. They could not rely on the

\footnotetext{
64 The Times, 22 May 1792.

65 The Times, 25 June 1792.

66 History of The Times, p. 43.

67 Black, 'The English Press in the Eighteenth Century', p. 99.

68 The Morning Chronicle, 23 September 1791.
} 
eyewitness accounts of other reporters, and - to make matters worse - the French papers were becoming less suitable sources of foreign news. When the Revolution entered a more radical phase, the counter-revolutionary and moderate French papers were stamped out, resulting in a far less diverse press. ${ }^{69}$ Thus, the Times complained in May 1792 that "The foreign Gazettes which chiefly guide the other Morning Prints, are become so extremely partial, that they aggravate or suppress almost every material fact, as suits the purpose of their several parties." ${ }^{70}$

By 1792, the Revolution debate had become so fraught that conductors not only faced the challenge of how to copy the eyewitness accounts of reporters with contrasting political opinions. They were questioning the very validity of the reports they received from sources that were not their own. Perry had demonstrated the benefits of having a reporter of one's own at the scene of events, and in the increasingly strained political climate of this revolutionary period, newspaper editors must have found it impossible to base their reports from France on copying and paraphrasing alone.

\footnotetext{
$69 \quad$ Popkin, Revolutionary News, p. 38.

70 The Times, 21 May 1792.
} 